\title{
Schinus Terebinthifolius Raddi, Popular Use, Chemical Composition, and Biological Activity: A Systematic Review
}

\author{
Ângela $\mathrm{F}^{1 *}$ and Luiz Filipe DS ${ }^{2}$ \\ ${ }^{1}$ Federal University of Pelotas, Brazil \\ 2Biologist MSc Diane Bender Almeida Schiavon
}

Research Article

Volume 1 Issue 4

Received Date: October 24, 2016

Published Date: December 05, 2016

*Corresponding author: Ângela Faccin, Veterinary MSc, University of Pelotas (UFPel), Campus Universitário s/n, Capão do Leão, RS Brazil, CEP 96010-900, E-mail: angefaccin@gmail.com

\section{Abstract}

Introduction: The advance of quantitative and qualitative research has been proving the use of plants as medicine. Considering that many people are adept at popular practices and Schinus terebinthifolis Raddi is native to South America, abundant in the coastal regions of Brazil, where it is popularly known as 'aroeira' (Brazilian peppertree).

Objective: Identify the primary studies regarding the popular use, chemical composition, and the main biological activities of Schinus terebinthifolis Raddi.

Metodology: This study attempted to identified, through a previous defined methodology, the systematic review, primary studies regarding the popular use, chemical composition, and the main biological activities of Schinus terebinthifolis Raddi. The survey was conducted in virtual libraries commonly accessed by the scientific community following a script execution and inclusion of some articles.

Results: After all steps of selection, we obtained a total of eighty-one, a number of studies on popular use, the chemical composition, and biological activities of the plant were achieved. The biological activity found and described for this plant is quite extensive. Thirty-eight works surveyed demonstrate that are several scientifically proven recommendations for using different parts of the plant.

Conclusion: This review enabled to systematize the knowledge produced on the main popular use, the main researches related to biological activity, and the range of chemical constituents of Schinus terebinthifolius Raddi already isolated.

Keywords: Brazilian peppertree (Schinus); Antimicrobial; Bioactive plants

\section{Introduction}

The use of plants for medicinal purposes formed the therapeutic basis of medical practice for several centuries [1]. According to World Health Organization (WHO) it is estimated that $80 \%$ of the population of the planet uses, somehow, bioactive plants as medicines [2]. The growing interest of the scientific community by herbal medicine in the last two decades led to the development of several practices and sayings-based researches [3].

Plants are responsible for producing a series of chemicals during their metabolism, some of these are known as active principle and are capable of causing 
some type of biological response when introduced in the body by any route, suggesting that the misuse of certain species as medicinal is very dangerous and may lead to side effects [4]. In recent years, the importance of herbal medicine was reaffirmed due to improvements in biological surveillance techniques and scientific validation [5].

Brazil presents a particularly rich medicinal flora that became the object of ethnopharmacological and ethnobotanical studies in the second half of nineteenth century and early twentieth century [6]. Among the plants of broad popular use is Schinus terebinthifolius Raddi [1]. This plant belongs to the family Anacardiaceae, and is a common plant of coastal vegetation [7]. It is popularly known in Brazil as "aroeira vermelha" or "pimenta rosa" [8]. It is a native plant to Brazil and was introduced in Europe where it is much admired for its beauty and size, and is used in urban streets afforestation [9]. It presents itself as a medium-sized tree, monoecious, with aromatic compound leaves which are used in cookery. In France it is named "poivre rose", a kind of sweet pepper [10]. It has abundant small red fruit during maturation [11]. The wood is hard and has multiple using including for production of charcoal and firewood [11]. This plant is widely used in Brazilian popular medicine and there are a growing number of studies about it in the medical literature [12].

The systematic review is a type of scientific inquiry that aims to gather, makes critical evaluation, and conducts a synthesis of multiple primary studies results [13]. In systematic reviews, the "subjects" of the investigation are the primary studies (units of analysis) selected through a systematic and pre-defined method. The systematic review is traditionally a retrospective study [14].

Due to the advancement in number and quality of the researches demonstrating the use of herbal medicine with some bioactive activity, and because many people are adept at popular practices, the objective of this research was to identify primary studies on popular using, chemical composition, and biological activities of Brazilian pepper tree - S. terebinthifolius Raddi.

\section{Material and Methods}

This systematic review study was conducted in the period from April 5 to May 5, 2012. It was made a survey of results in databases SciELO, PubMed, and Scholar Google, in any date of publication. SciELO -- Scientific Eletronic Library Online - was chosen because it contains studies from Latin America, Spain and Portugal, PubMed, by bringing together leading medical studies, and Google Scholar was used in this study with the main objective to find studies that are not indexed in journals published regionally, including thesis, dissertations, and conferences. The search strategy in SciELO and PubMed was the use of the keyword "Schinus terebinthifolius". Two different surveys were made in Google Scholar, with results only in Portuguese, and the keyword anywhere in the text, in the first search the term "Schinus terebinthifolius" was used on "with all the words" and the term "popular usage" on "with the exact phrase". In the second search term "Schinus terebinthifolius" was used on "all the words", and the term chemical composition was used on "with the exact phrase".

After searching, all studies found were selected and filed away. The titles and the abstracts of all articles were read, and a second selection was done for discarding those results that did not fit the purpose of the search. A third selection was made with a complete reading of all texts selected in the second step. Thus, the total result of the studies that formed this review was achieved. The selection criteria adopted were the articles of primary knowledge that dealt with the popular usage of the plant, its chemical composition, and the main biological activities in healthcare.

\section{Results}

The selection of results found, as show in Figure 1, resulted in 81 publications, covering papers, Regional publications, conferences publications, and thesis and dissertations.

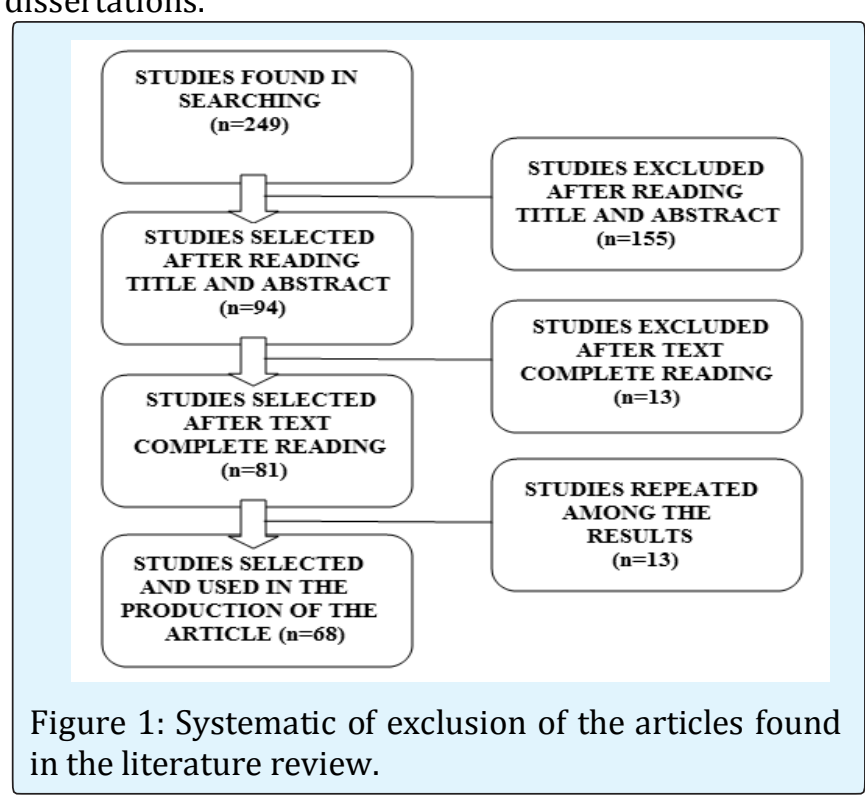


Out of 81 selected articles, 13 were repeated among searching, that is, appeared as a result in more than one search base. Therefore, the total of publications used in this article comprises 68 files. Among the search bases, we obtained results as shown in Table 1. Focusing the popular usage 18 articles was found, on chemical composition 12 articles were found, and 38 dealt with the evaluation of biological activity of plant extracts which allowed the completion of data.

\begin{tabular}{|c|c|c|c|c|c|}
\hline & SciELO & PubMed & $\begin{array}{c}\text { GA -chemical } \\
\text { composition* }\end{array}$ & $\begin{array}{c}\text { GA - popular } \\
\text { usage }^{* *}\end{array}$ & TOTAL \\
\hline Results 1st searching & 44 & 35 & 111 & 59 & 249 \\
\hline After 1st reading & 22 & 23 & 26 & 23 & 94 \\
\hline After 2nd reading & 19 & 21 & 21 & 20 & $81^{* * *}$ \\
\hline
\end{tabular}

Table 1: Results obtained based on the search at each stage of selection.

*GA - chemical composition: Google Scholar, with the exact phrase "chemical composition"

**GA - popular usage: Google Scholar, with the exact phrase "popular usage"

*** 13 articles were repeated in different search bases

\section{Discussion}

Over the years, popular observations have led to the accumulation of relevant information of the effectiveness and the medicinal effects of the plants [15]. According to Guerra et al. who conducted a study on the use of herbal medicine practice in a particular rural village, the reality in these communities is that the predominance of the use of medicinal herbs is due to the traditional habit of people seeking healing from sickness taking advantage of existing resources in their environment [16]. In accordance to this, others authors, have also conducted similar studies investigating and doing a survey about which species were most commonly used by regional populations [4,6,17-29].

Among these investigative studies with different regional groups, the main popular indications for using Brazilian peppertree are related to oral pathologies 28$20-18$, because of its healing action $19-25$, or as an antiseptic 24. According to the study by Boscolo et al. the bark of the trunk and fruit of this plant are indicated for respiratory disorders and uterine inflammation [4]. Lopes reported that the decoctions of bark and leaves are used for healing, for stanching bleeding and even for strengthening teeth [22]. As the aforementioned authors, Guerra et al. restated what has been described pointing the popular usage for Schinus bark in different forms of extraction, the cooking is useful for inflammation and ulcers, infusion is useful in injuries, bruises, and inflammation, syrup is indicated in case of influenza, and bark powder and macerated bark are used for healing injuries and bruises [16]. Mentz et al. suggested that the infusion of the leaves is effective for digestive disturbances, or even that baths have depurative and antirheumatic action [6]. Regarding this use, Silva et al. also found the popular usage of this plant for gastrointestinal disorders [26]. Fenner et al. investigated plants to be used as popular antifungal medicine and highlighted Schinus as one of them [30].

Oliveira et al. and Carriconde, wrote booklets containing the main medicinal plants of popular use in the states of Paraiba and Pernambuco (Brazil), demonstrating how to collect, dry and prepare the plants to be used, as well the indicated amount and for how long it should be used, based on information obtained in the popular investigation [31-32].

Regarding its composition, a number of authors describe the isolation of chemicals from several portions and different plant extracts. Richter et al. suggest a new chromatography technique used to insulate chemical compounds of essential oil from the Schinus fruit [33].

Clemente performed the chemical analysis of the essential oil of Schinus terebintifolius Raddi [34], and other authors have also investigated its essential oils composition, as shown in Table 2. 


\section{Open Access Journal of Veterinary Science \& Research}

\begin{tabular}{|c|c|c|c|}
\hline Plant Part & Extract & Main compounds & Ref. \\
\hline Leaf & Essential oil & $\begin{array}{c}\text { Monoterpenes/Oxygenated Monoterpenes/Sesqueterpenes/ } \\
\text { Oxigenated/Sesqueterpenes }\end{array}$ & 12 \\
\hline Leaf & Essential oil & Sabinene/Alpha-pinene/Cariophyllene/D-Germacrene & 35 \\
\hline Leaf & EHA & Ehyl gallate/Myricetin/Methyl gallate & 36 \\
\hline Fruit & Essential oil & Monoterpene & 8 \\
\hline Fruit & Essential oil & Alpha-pinene/Delta-carene/limonene/Alpha-phellandrene & 37 \\
\hline Fruit & Essential oil & Sesquiterpene & 38 \\
\hline Bark & Decoction & Tannins & 39 \\
\hline
\end{tabular}

Table 2: Chemical composition of S. terebinthifolius Raddi described by different authors

El-Massry et al. by chromatography of the essential oil from Schinus leaves, found monoterpenes, sesquiterpenes, oxygenated monoterpenes, and oxygenated monoterpenes [40]. Roveda et al. have also observed monoterpenes concentration, but in essential oil of the fruit [8]. Silva et al. have isolated alpha-pinene, deltacarene, limonene, and alpha-phellandrene from fruit essential oil, in their investigation [37].

Santos et al. by evaluating chemical changes in the essential oil of the leaves from three exemplars of the plant, in different phonological phases, identified sabinene, alpha-pinene, cariophyllene, and germacrene D as main substances [35]. The samples were different from each other in relation to their main components. However, the authors suggested that the differences may be related to genetic character, micro-environment, and physiological age of the trees.

Hayashi et al. isolated a xanthine oxidase inhibitor [36]. Ceruks et al. made a phytochemical study of hydroalcoholic extract of Schinus leaves, and isolated ethyl gallate, myricetin, and methyl gallate [10]. Barca studied the decoction of Schinus bark and concluded that it has a high amount of tannins, making it an antiinflammatory and astringent plant, by causing local vasoconstriction and coagulation of proteins, forming a coat slightly antiseptic, and under it the tissue regeneration occurs [39]. In relation to influences on the extract, Vasconcelos et al. evaluated the influence of temperature for obtaining the plant extract in their final product [41].

Bendaoud et al. isolated the sesqueterpene compound from essential oil of Schinus fruits, which had an action against breast cancer in humans, according their researches [38]. Another similar study Queires et al. researched the effects of polyphenols isolated from Schinus and its activity against prostate carcinoma [42]. Jain et al. evaluated a terpenoid, the schinol, to test the inhibition of phospholipase A2 [43]. Tirelli et al. quantified tannins in Schinus bark and compared with other plants [44].

Taking into account the different biological activities of Schinus terebinthifolius Raddi, the findings were various. As for activity against bacteria, Costa et al. evaluated four extracts from different plants against Enterococus faecalis, an important dental oral bacteria, revealing the antibacterial action of the Schinus extract. Similarly, Lima et al. tested the ethanol extract of the stem bark and leaves, as well as some fractions of these extracts, against certain susceptible strains of Staphylococcus aureus and Escherichia coli, and resistant strains of Staphylococcus aureus [45-46]. Melo et al. verified the activity of Schinus against bacteria isolated from alveolitis in rats, and the plant achieved an efficient outcome [5]. Silva et al. aimed to test the essential oil from the leaves of Schinus against Staphylococcus spp. isolated from external otitis in canines and evaluated cytotoxicity with laboratory animals, concluding that the extract has a potent antimicrobial action and no evidence of toxicity [37].

According to Amorim et al. women from northeastern Brazil often use Schinus decoction for treating vaginitis and cervicitis [47]. In this study they have shown the in vivo use, with significant results in the treatment of bacterial vaginosis. Leite et al. conducted a very similar study, comparing the use of Schinus and metronidazole in the treatment of bacterial vaginosis, but the antibiotic had a higher cure rate [48].

Santos et al. evaluated the effect of Schinus leaves extract against some species of fungus isolated from flowers which showed growth inhibition of Colletotrichum 
spp and Fusarium spp [49]. Ruiz et al. evaluated thirteen herbal plants, including Schinus, to test their mutagenic properties against Aspergillus nidulans, and showed that only one, Momordica charantia, had genotoxic effect [50].

Johann et al. investigated the antifungal effect of various plants against Paracoccidioides brasiliensis, and Schinus was not among the plants with best results [51]. But in another study Johann et al. using hydro alcoholic extract from leaves and bark of Schinus, isolated some compounds, among them, schinol and NC-byphenil were active against the fungus Paracoccidioides brasiliensis. In this study they also found that portion schinol combined with Itraconazole showed synergistic effect [52].

Tonial, showed the antimicrobial activity of methanol extract of Schinus leaves [53]. Schmourlo et al. evaluated the activity of the plant against some yeasts of Candida, Trichophyton and Cryptococcus genera [54]. Schinus showed positive results against Candida spp. Similarly, Guerra et al. tested the fluid extract of Schinus terebinthifolius Raddi leaves aginst Staphylococcus aureus, Escherichia coli, Pseudomonas aeruginosa, and Candida albicans [55]. They obtained a positive result, but with a broader action against the yeast. Santos, tested the action of Schinus extract against Staphylococcus aureus, Pseudomonas aeruginosa, Escherichia coli, Bacilus subtilis, Candida albicans, Candida tropicalis, Candida krusei, Candida guillermondii, Trichophyton rubrum, Microsporum gypseum, Aspergillus flavus, and Aspergillus niger [56]. The results were positive for bacteria, but ineffective against fungi. Pereira et al. also tested ethanol extract from some plants, including Schinus, against various microorganisms: Candida albicans, Streptococcus mutans, Staphylococcus aureus, and Aggregatibacter actinomycetemcomitans, and the extracts showed some antimicrobial activity [57].

There are different results regarding the healing mediated by the Schinus extract. The healing activity was showed in the nineteenth and early twentieth centuries with experiments in rats with hydroalcoholic extract of bark, in bladder Lucenaa et al. linea Alba Nunes et al. and colon Coutinho et al.[2-7-12]. However, in the same biological model, Santos et al. used a similar protocol and evaluated the healing of the stomach and observed that there was no change in the healing process [3]. BrancoNeto et al. used a different technique from the others, by evaluating the topical use of the plant in the healing dorsal wounds in rats, and observed that the extract delayed the reepithelialization of skin woods [1].
Lipinski, compared the effect of Schinus bark with other plants on wound healing process by secondary intention in cattle, resulting in a beneficial effect of this plant [58]. Lanzoni, verified the action of polar and non polar extracts of Schinus leaves, as well as their combination, in tissue repair of induced transfixing lesions in rats tongue [59]. Polar extract was more effective in the initial process of repair, and non polar extract was the best in collagen production and repair of ulcers. Ribas et al. evaluated the tissue repair in ulcerated lesions on the oral mucosa of rats and also found positive results [9].

Medeiros et al. tested the anti-inflammatory action of a compound formed by four plants, including Schinus, popularly used in northeastern Brazil, in experimental studies with ear and paw edema in rats [60]. The compound showed anti-inflammatory property, and the recommended dose is the same used by the population. The same product was tested by Paulo et al. for toxicological effects [61]. These authors conducted toxicological clinical trials, phase 1 , in human beings, using an herbal product, and proved that it has low toxicity. In in vivo assays, Lima et al. evaluated hydro alcoholic extract toxicity of Schinus bark on rats, and concluded that the plant produces no toxic effects [62].

An interesting biological activity, concerning the use of Schinus terebinthifolius Raddi, is described by Silva et al. and Silva et al. who state that the essential oil obtained from Schinus fruits is an alternative to antibiotics in the feed of broilers, because it improves production rates and intestinal absorptive surface, promoting better feed conversion, weight gain, and final weight [63-64].

Previous studies, with scientific impact, on the action of medicinal plants against tumor cells, were performed. Barbosa evaluated the toxicological effects of some plants, including Schinus, and analyzed the action of their extracts on tumor cells [65]. Mesquita, evaluated the action of various extracts of plants from Brazilian savanna against three human cancer cell lines - melanoma, colon, and glioblastome [11]. Schinus was classified as active against those cells.

Varela-Barca et al. argued that Schinus has genotoxic properties and claimed that its flavonoid fractions cause damage to bacterial DNA. The DNA is the target for Fpg formamidopyrimidine-DNA-glycosylase and MutYglycosylase, via BER -Base Excision Repair [66]. Similarly, Carvalho et al. by the trunk bark decoction, found several components and attributed to the antioxidant potential flavonoids [67]. In this study, the extract caused damage 
and mutation in bacterial DNA, suggesting a kind of plant action on these microorganisms, and it is of utmost importance for the scientific substantiation of the use of medicinal plants.

Other activities related to Schinus are described by Bertoldi, who evaluated the performance and the antioxidant potential of the phenolic fraction of the essential oil and oleoresin [15]. Machado et al. investigated experimentally the anti allergic of ethyl acetate fraction of Schinus which showed positive results, proving this indication [68].

Freitas et al. in a palynological analisis, from the removal of wax and the resin, cited Schinus as being a component of brown propolis from Atlantic Forest of Rio de Janeiro (Brazil) [69]. Teixeira, also pointed out Schinus as a component of propolis originating from three regions de state of Minas Gerais (Brazil), and assigned the complexity of propolis chemical composition to valuable pharmacological properties, considering some compounds alone, or the synergism between them, which leads to a broad spectrum activity against different microorganisms of varying degrees of pathogenicity for man and other animals [70]. He also cited important studies on proven biological properties, as antioxidant, cytotoxic, and immunomodulatory actions.

\section{Conclusions}

This review enabled to systematize the knowledge produced on the main popular use, the main researches related to biological activity, and the range of chemical constituents of Schinus terebinthifolius Raddi already isolated. It was possible to demonstrate the richness and the high potential of this bioactive medicinal plant, but it needs more research to deepen knowledge and its therapeutic use.

\section{References}

1. Branco-Neto MLC, Ribas-Filho JM, Malafaia 0, Oliveira-Filho MA, Czeczko NG, et al. (2006) Avaliação do extrato hidroalcoolico de aroeira (Schinus terebinthifolius Raddi) no processo de cicatrização de feridas em peles de ratos. Act Cir Bras 21(2): 17-22.

2. Lucena PLH, Ribas-Filho JM, Nascimento MM, Czeczko NG, Correa-Neto MA, et al. (2006) Avaliação da ação da aroeira (Schins terebinthifolius Raddi) na cicatrização de feridas cirúrgicas em bexiga de ratos. Acta Cir Bras 21(2): 46-51.

Ângela F, et al. Schinus Terebinthifolius Raddi, Popular Use, Chemical Composition, and Biological Activity: A Systematic Review. J Vet Sci Res 2016, 1(4): 000119.
3. Santos OJ, Ribas-Filho JM, Czeczko NG, Branco Neto MLC, Naufel Jr CR, et al. (2006) Avaliação do extrato de aroeira (Schinus terebinthifolius Raddi) no processo de cicatrização de gastrorrafias em ratos. Acta Cir Bras 21(2): 39-45.

4. Boscolo O, Valle LS. (2008) Plantas de uso medicinal em Quissamã, Rio de Janeiro, Brasil. Ser Bot 63(2): 263-277.

5. Melo Jr EJM, Raposo MJ, Lisboa Neto JÁ, Diniz MFA, Marcelino Jr CAC, et al. (2002) Medicinal plants in the healing of dry socket in rats: microbiological and microscopic analysis. Phytomedicine 9(2): 109-116.

6. Mentz LA, Lutzemberger LC, Schenkel EP (1997) Da flora medicinal do Rio Grande do Sul: notas sobre a obra de D’Ávila (1910). Cad Farm 13(1): 25-48.

7. Nunes Jr JAT, Ribas-Filho JM, Malafia O, Czeczko NG, Inácio CM, et al. (2006) Avaliação do efeito do extrato hidroalcoolico de Schinus terebinthifolius Raddi (aroeira) no processo de cicatrização da línea Alba de ratos. Acta Cir. Bras 21(3): 8-15.

8. Roveda LM, Formagio ASN, Baldinia DS, Santos LAC, Vieira MC, et al. (2010) Composição química e avaliação da atividade antitumoral do óleo essencial de Schinus terebinthifolius Raddi (Anacardiaceae). In: $10^{\circ}$ Simpósio Brasil-Japão, 2010 Out; Campo Grande Brasil. São Paulo: Associação Brasil-Japão de Pesquisadores 10(1): 1-3.

9. Ribas MO, Sousa MH, Sartoretto J, Lanzoni TA, Noronha L, et al (2006) Efeito da Schinus terebinthifolius Raddi sobre o processo de reparo tecidual das lesões ulceradas induzidas na mucosa bucal do rato. Rev Odonto Ciênc 21(53): 245-252.

10. Ceruks M, Romoff P, Fávero AO, Lago JHG. (2007) Constituintes fenólicos polares de Schinus terebinthifolius Raddi (Anacardiaceae). Quim Nova 30(3): 597-599.

11. Mesquita ML. (2009) Potencial antitumoral de substâncias isoladas de plantas do Cerrado brasileiro: estudos preliminares do mecanismo de ação da atividade citotóxica [PhD Thesis]. Brasília, Brasil: Universidade de Brasília.

12. Coutinho IHILS, Torres OJM, Matias JEF, Coelho JCU, Sahlke Júnior HJ, et al. (2006) Efeito do extrato hidroalcoolico de aroeira (Schinus terebinthifolius Raddi) na cicatrização de anastomoses colônicas. 


\section{Open Access Journal of Veterinary Science \& Research}

Estudo experimental em ratos. Acta Cir Bras 21(3): 49-54.

13. Cook DJ, Mulrow CD, Haynes RB (1997) Systematic reviews: synthesis of best evidence for clinical decisions. In: Annais of Internal Medicine 126(5): 376-380.

14. Cordeiro AM, Oliveira GM, Renteria JM, Guimarães CA (2007) Revisão sistemática: uma revisão narrativa. Rev Col Bras Cir 34(6): 428-431.

15. Bertoldi MC (2006) Atividade antioxidante in vitro da fração fenólica, das oleorresinas e do óleo essencial de pimenta rosa (Schinus terebinthifolius Raddi). Viçosa, Brasil: Universidade federal de Viçosa.

16. Guerra AMNM, Pessoa MF, Souza CSM, Maracajá PB (2010) Utilização de plantas medicinais pela comunidade rural Moacir Lucena. Biosci J 26(3): 442450 .

17. Braga R (1908) Plantas do Ceará. Rev Inst Ceará. 2 edição: 21-62.

18. Cavalcante ALFA (2010) Plantas medicinais e saúde bucal; estudo etnobotânco, atividade antimicrobiana e potencial para interação medicamentosa. João Pessoas, Brasil: Universidade Federal de Paraíba.

19. Ferraz LS, Alburqerque ES, Silva JAA, Oliveira KCL, Galdino RMN (2009) Levantamento da diversidade das plantas medicinais utilizadas pela comunidade do Curado. In: Universidade Federal Rural de Pernambuco, Recife, Brasil. UFRPE: Pró reitoria de atividade de extensão 1-3.

20. Francisco KSF (2010) Fitoterapia: uma opção para o tratamento odontológico. Rev Saúde 4(1): 18-24.

21. Lamar AS, Lopez GF, Trujillo NC, Fuentes DF (2000) Propuesta de ruta critica para la evaluacion genotoxica de plantas medicinales en Cuba Rev Cubana Farm 34(1): 34-43.

22. Lopes CVG (2010) O conhecimento etnobotânico da comunidade quilombola do Varzeão, Dr. Ulysses (PR): no contexto do desenvolvimento rural sustentável. Curitiba, Brasil: Universidade Federal do Paraná.

23. Mazza MCM, Rodigheri HR, Nakashima T, Ziller SR, Mazza CAS, et al. (2000) Potencial de aproveitamento medicinal de espécies do sub-bosque dos bracatingas da região de Curitiba PR. In: Embrapa Florestas, 2000
Dez; Colombo, Brasil. Colombo: Embrapa Florestas, documentos 43, 01-27.

24. Medeiros MFT, Senna-Valle L, Andreata RHP (2005) Flora medicinal dos sitiantes da reserva particular do patrimônio natural Rios das Pedras, Mangaratiba, Rio de Janeiro, Brasil: taxonomia e aspectos etnobotânicos. In: Publicações Avulsas do Museu Nacional do Rio de Janeiro, 2005; Rio de Janeiro: Museu Nacional do Rio de Janeiro 106(3): 03-24.

25. Moreira RCT, Costa LCB, Costa RCS, Rocha EA. (2002) Abordagem etnobotânica acerca do uso de plantas medicinais na Vila Cachoeira, Ilheus, BA, Brasil. Acta Farm Bonaerense 21(3): 205-211.

26. Pereira RC, Oliveira MTR, Lemos GCS. (2005) Plantas utilizadas como medicinais no município de Campos de Goytacazes - RJ Rev Bras Farmacogn 14(0): 37-40.

27. Pereira IGR (2008) Prevalência do uso de fitoterapia em pacientes do programa de geriatria do hospital universitário de Brasília - HUB. Brasília, Brasil: Universidade de Brasília.

28. Santos EB, Dantas GS, Santos HB, Diniz MFFM, Sampaio FC (2009) Estudo etnobotânico de plantas medicinais para problemas bucais no município de João Pessoa, Brasil Rev Bras Farmacogn. 19(1B): 321324.

29. Silva MS, Antoniolli AR, Batista JS, Mota CN (2006) Plantas medicinais usadas nos distúrbios do trato gastrointestinais no povoado Colônia Treze, Lagarto, SE, Brasil. Acta bot Bras 20(4): 815-829.

30. Fenner R, Betti AH, Mentz LA, Rates SMK (2006) Plantas utilizadas na medicina popular brasileira com potencial atividade antifúngica. Rev Bras Cienc Farm 42(3): 371-394.

31. Oliveira LCP, Figeiredo CA, Oashi EG, Sousa MS (2010) Manual de plantas medicinais de interesse no SUS. In: XII Encontro de Iniciação a Docência, 2010 Out; João Pessoa Brasil. João Pessoa: Universidade Federal da Paraíba 13(0): 01-9.

32. Carriconde C (1999) Cartilha para agentes comunitários de saúde do agreste. In: Centro nordestino de medicina popular, Olinda Brasil. Sudene - Superintendência do Desenvolvimento do Nordeste 01-34. 


\section{Open Access Journal of Veterinary Science \& Research}

33. Richter R, von Reuß SH, König WA (2010) Spirocyclopropane-type sesquiterpene hydrocarbons from Schinus terebinthifolius Raddi. Phytochemistry 71(1): 1371-1374.

34. Clemente AD (2006) Composição química e atividade biológica do óleo essencial da pimenta-rosa (Schinus terebinthifolius Raddi). Viçosa, Brasil: Universidade Federal de Viçosa.

35. Santos ACA, Agostini F, Santos PL, Serafini LA, Moyna $\mathrm{P}$, et al. (2007) Avaliação química mensal de três exemplares de Schinus terebinthifolius Raddi. Rev Bras Biocien 5(2): 1011-1113.

36. Hayashi T, Nagayama K, Arisawa M, Shimizu M, Suzuki S (1989) Pentagalloylglucose, a xanthine oxidase inhibitor from a Paraguayan crude drug, "molle I" (Schinus terebinthifolius) J Nat Prod 52(1): 210-211.

37. Silva AB, Silva T, Fanco ES, Rabelo AS, Lima ER, et al. (2010) Antibacterial active, chemical composition, and cytotoxicity of leaf's essential oil from brazilian pepper tree (Schinus terebinthifolius Raddi). Braz J Microbiol 41(1): 158-163.

38. Bendaoud H, Romdhane M, Souchard JP, Cazaux S, Bouajila J (2010) Chemical composition and anticancer and antioxidant activities of Schinus molle $\mathrm{L}$ and Schinus terebinthifolius Raddi bevies essential oils. J Food Scien 75(6): 466-472.

39. Barca FNTV (2008) Metagênese induzida por flavonóides presentes no decocto das cascas da aroeira (Schinus terebinthifolius Raddi). Natal, Brasil: Universidade Federal do Rio Grande do Norte.

40. El-Massry KF, El-Ghorab AH, Shaaban HA, Shibamoto $T$ (2009) Chemical compositions and antioxidant/antimicrobial activities of various samples prepared from Schinus terebinthifolius leaves cultivated in Egypt. J Agric Food Chem 57(12): 52655270 .

41. Vasconcelos EAF, Medeiros MGF, Raffin FN, Moura TFAL (2005) Influência da temperatura de secagem e da concentração de Aerosil@200 nas características dos extratos secos por aspersão da Schinus terebinthifolius Raddi (Anacardiaceae). Rev Bras Farmacogn 15(3): 243-249.

42. Queires LCS, Lafève-Favel F, Terry S, La Taille A, Kouyoumdjian JC, et al. (2006) Polyphenols purified from the brazilian aroeira plant (Schins terebinthifolius, Raddi) induce apoptotic and autophagic cell death of DU145 cells. Anticancer Res 26(1A): 379-388.

43. Jain MK, Yu BZ, Rogers JM, Smith AM, Borger ETA, et al. (1995) Specific competitive inhibitor of secreted phospholipase A2 from berries of Schinus terebinthifolius. Phytochemistry 39(3): 537-547.

44. Tirelli AA, Alves DS, Carvalho GA, Sâmia RR, Brum SS, et al. (2010) Efeitos de frações tânicas sobre parâmetros biológicos e nutricionais de Spodoptera frugiperda (Lepidóptera: noctuidae). Ciênc. Agrotec 34(6): 1417-1424.

45. Costa EMMB, Barbosa AS, Arruda TA, Oliveira PT, Dametto FR, et al. (2010) Estudo in vitro da ação antimicrobiana de extrato de plantas contra Enterococcus fecalis. J Bras Patol Med Lab 46(3): 175180.

46. Lima MRF, Luna JS, Santos AF, Andrade MCC, Sant'ana AEG, et al. (2006) Anti-bacterial activity of some brazilian medicinal plants. Journal of Ethnopharmacol 105(1-2): 137-147.

47. Amorim MMR, Santos LC (2003) Tratamento da vaginose bacteriana com gel vaginal de aroeira (Schinus terebinthifolius Raddi): Ensaio clínico randomizado. Rev Bras Ginecol Obstet 25(2): 95-102.

48. Leite SRRF, Amorim MMR, Sereno PFB, Leite TNF, Ferreira JAC, et al. (2011) Randomized clinical trial comparing the efficacy of the vaginal use of metronidazole with a brazilian pepper tree (Schinus) extract for the treatment of bacterial vaginosis. Braz J Med Biol Res 44(3): 245-252.

49. Santos ACA, Rossato M, Serafini LA, Bueno M, Crippa LB, Sartori VC, et al. (2010) Efeito fungicida dos óleos essenciais de Schinus molle L. e Schinus terebinthifolius Raddi, Anacardiaceae, do Rio Grande do Sul Rev Bras Farmacogn 20(2): 154-159.

50. Ruiz AR, La Torre RA, Alonso N, Villaescura A, Betancurt J, et al. (1996) Screening of medicinal plants for induction of somatic segregation activity in Aspergillus nidulans. J Ethnopharmacology 52(3): 123-127.

51. Johann S, Cisalpino PS, Watanabe GA, Cota BB, Siqueira EP, et al. (2010) Antifungal activity of extracts of some plants used in brazilian traditional 


\section{Open Access Journal of Veterinary Science \& Research}

medicine against the pathogenic fungus Paracoccidioides brasiliensis. Pharm Biol 48(4): 388396.

52. Johann S, Sá NP, Lima LARS, Cisalpino PS, Cota BB, et al. (2010) Antifungal activity of schinol and a new biphenyl compound isolated from Schinus terebinthifolius against the pathogenic fungus Paracoccidioides brasiliensis. Ann Clin Microbiol Antimicrob 9(30): 1-6.

53. Tonial F (2010) Atividade antimicrobiana de endófitos e de extratos foliares de Schinus terebinthifolis Raddi (Aroeira). Curitiba, Brasil: Universidade Federal do Paraná.

54. Schmourlo G, Mendonça-Filho RR, Alviano CS, Costa SS (2005) Screening of antifungal agents using ethanol precipitation and bioautography of medicinal and food plants. J Ethnopharmacol 96(3): 563-568.

55. Guerra MJM, Barreiro LM, Rodríguez MZ, Rubalcaba Y (2000) Actividad antimicrobiana de um extracto fluido al $80 \%$ de Schinus terebinthifolius Raddi (copal). Rev Cubana Plant Med 5(1): 23-25.

56. Santos ALR (2007) Avaliação do sistema conservante em formulação com extrato hiroalcoolico de Schinus terebinthifolius Raddi - Anacardiaceae. Natal, Brasil: Universidade federal do Rio Grande do Norte.

57. Pereira EMR, Gomes RT, Freire NR, Aguiar EG, Brandão MGL, et al. (2011) In vitro antimicrobial activity of brazilian medicinal plant extract against pathopgenic microorganisms of interest to dentistry. Planta Med 77(1): 401-404.

58. Lipinski LC (2008) Comparação da atividade cicatrizante na pele bovina entre fitoterápicos de uso tópico. Curitiba, Brasil: Universidade Federal do Paraná.

59. Lanzoni TA (2007) Efeito dos extratos das folhas da Schinus terebinthifolius Raddi (Aroeira) sobre lesões transfixantes induzidas na língua de ratos. Curitiba, Brasil: Universidade Católica do Paraná.

60. Medeiros KCP, Monteiro JC, Diniz MFFM, Medeiros IA, Silva BA, (2007) Effect of the activity of the brazilian polyherbal formulation: Eucalyptus globulus Labill, Peltodon radicans Pohl and Schinus terebinthifolius Radd, in inflammatory models. Rev Bras Farmacogn 17(1): 23-28.
61. Paulo PTC, Diniz MFFM, Medeiros IA, Morais LCSL, Andrade FB, et al. (2009) Ensaios clínicos toxicológicos, fase I, de um fitoterápico composto (Schinus terebinthifolius Raddi, Plectrantus amboinicus Lour e Eucalyptus globulus Labill). Rev Bras Farmacogn 19(1A): 68-76.

62. Lima LB, Vasconcelos CFB, Maranhão HML, Leite VR, Ferreira PA, et al. (2009) Acute and subacute toxity of Schinus terebinthifolius bark extract. J Ethnopharmacol 126(3): 468-473.

63. Silva MA, Pessotti BMS, Zanini SF, Colnago GL, Nunes LC, et al. (2010) Óleo de aroeira-vermelha sobre o desempenho e a morfometria intestinal de frangos de corte. Cienc Rural 40(10): 2151-2156.

64. Silva MA, Pessoti BMS, Zanini SF, Colnago GL, Nunes LC, et al. (2011) Óleo essencial de aroeira-vermelha como aditivo na ração de frangos de corte. Cienc Rural 41(4): 676-681.

65. Barbosa CV (2009) Avaliação do potencial antineoplásico de plantas medicinais utilizadas como coadjuvantes no tratamento do câncer pelos pacientes do CACON/UFAL. Maceió, Brasil: Universidade Federal de Alagoas.

66. Varela-Barca FNT, Agnez-Lima LF, Medeiros SRB (2011) Base excision repair pathway is involved in the repair of lesions generated by flavanoid-enriched fractions of pepper tree (Schinus terebinthifolius Raddi) stem bark. Environ Mol Mutagen 48(8): 672681.

67. Carvalho MCRD, Barca FNTV, Agnez-Lima LF, Medeiros SRB (2003) Evaluation of mutagenic activity in an extract of pepper tree stem bark (Schinus terebinthifolius Raddi). Environ Mol Mutagen 42(1): 185-191.

68. Machado SCC, Rosas EC, Brito FA, Heringe AP, Oliveira $\mathrm{RR}$, et al. (2008) The anti-allergic activity of the acetate fraction of Schinus terebinthifolius leaves in IgE induced mice paw edema and pleurisy. Int Immunopharmacol 8(11): 1552-1560.

69. Freitas AS, Barth OM, Luz CFP (2010) Própolis Marrom da vertente Atlântica do estado do Rio de Janeiro, Brasil: uma avaliação palinológica. Revista Brasil Bot 33(2): 343-354. 


\section{Open Access Journal of Veterinary Science \& Research}

70. Teixeira EW (2003) Identificação de espécies vegetais componentes da própolis originária de três regiões de Minas gerais e suas atividades biológicas. Viçosa, Brasil: Universidade Federal de Viçosa. 